\title{
The Impact of Economic Crisis in Greece: Key Facts and an Overview of the Banking Sector
}

\author{
Fotios V. Mitsakis \\ Dept. of Human Resource Management, University of Strathclyde \\ Glasgow G1 1XU, Scotland \\ E-mail: fotis.mitsakis@strath.ac.uk,fotisathens@hotmail.com
}

Received: March 27, 2014 Accepted: April 15, 2014

doi:10.5296/ber.v4i1.5515 URL: http://dx.doi.org/10.5296/ber.v4i1.5515

\begin{abstract}
Nowadays, the global economic crisis (GEC) highly influences organizations through its macroeconomic causes and effects, which account for a significant impact on firms' human resources (HR) practices and labor relations (IR) as well. Of greatest concern is the extent to which the actual impacts of the crisis may be hoarding future problems for organization's operations. Owing to the dynamic nature of contemporary business, its complexity, along with the increasing need for expertise, strategic HR interventions are highly required in an attempt of creating mature and resilient, in HR terms, organizations which will be able to assure their competitiveness, survival, change and growth. However, most organizations (banks) failed to adequately finance their daily operations, accompanied by their failure to finance national economies as well. In that event, the straightaway effects of GEC have resulted into a collapse of most financial systems and in major shortages at financial institutions around the globe. The purpose of this paper is to highlight the impact of GEC through demonstrating key facts related to the current economic crisis in Greece, and more precisely for Greek banking organizations.
\end{abstract}

Keywords: Economic Crisis (EC), Greek Banks, Human Resources (HR)

\section{Introduction}

The GEC, the deepest the world has experienced since the stock market crash in 1930s, originated in the US mortgage market, leading to a liquidity shortfall in its banking system, the full effect of which started to be felt in August 2007 (Soriano, 2011), although, Appelbaum (2011: 597) believes that the crisis did not originate in financial markets, but its direct cause initiated by the bursting of the housing bubble. Eventually, the financial crisis initiated in US impacted upon the world economy and led to global trade's collapse 
(Appelbaum, 2011). The second phase of GEC began in September 2008 with the fall of Lehman Brothers; it was more intense and resulted to a general loss of confidence and solvency problems in many financial institutions across the globe. Whilst the crisis has been more concentrated in the financial systems of US and Europe, it has ultimately affected the real economies of all developed and emerging countries, including Greece. Even though this economic hardship did not impact all European Union (EU) countries at the same intensity, its effects were almost similar for all of its member states (European Commission, 2010). The particularity of the current crisis is that it combines a financial crisis originating in the largest world economy (US), along with a global downturn that weight heavily on everyone's mind (Soriano, 2011). Apparently, GEC's severity targeted almost the majority of nations and businesses, no matter of each country's or organization's level of competitiveness.

\section{Methodological Approach}

As afore stated, the purpose of this paper is to highlight the impact of the EC through demonstrating key facts related to the current economic crisis in Greece, and more precisely for Greek banking organizations. To that end, to serve its purpose, it was decided to conduct an extensive and thoughtful review and retrieve of relevant literature, along with assessing germane journal articles, reports, dissertations and other documents discussing the impact of GEC in banking institutions. In that event, a careful keyword search was conducted through assessing several databases (e.g. Web of knowledge, British library Ethos, EBSCO library, Social Science Research Network -SSRN library, Science Direct, Strathclyde online database etc.). Additionally, Google Scholar was utilized as the major search engine, by limiting the research to those articles straight referring to GEC, banks, and human resources in crisis, either published in Greek or English. The resulting material included a vast majority of journal articles, reports and practice-related documents. Both a "concept-centric" and "structured" approach was used in order to audit, segregate and decide which sources to review and include in this review paper. All documents were further listed into specific key themes (e.g. economic crisis, banking institutions, human resources etc.) to assist the author for further analysis and consideration. To that end, all of the referenced resources provided the necessary information from which evidence and conclusions were drawn.

\section{The Impact of Economic Crisis in Greece: Key Facts}

The impact of EC in Greece was, and still remains, quite severe. During the first phase of the GEC, the Greek economy managed to avoid serious shocks. GEC's impact delayed to affect Greece, due to the fact that its economy is a relatively closed economy, along with some favorable factors from past years, such as the great effort of the Greek government of improving its economy, and more precisely, the diminution of its inflation and budget deficits in the period before 2001, owing to its efforts to become European Union's (EU) member (Moschos \& Chortareas, 2013).

From 2000 to 2007, Greece had one of the fastest growing economies in the Eurozone (Gross Domestic Product (GDP) annual rate of 4.2\%), as foreign investments and capitals entered the country (Nelson et al., 2011). Besides the stability brought about by the adoption of the common currency and the participation in Eurozone, Greek economy was further strengthened, 
the previous years, by high inflows of EU Structural Funds for infrastructure projects in view of the Olympic Games in Athens in 2004, the making of several structural reforms, and banking system's contribution after its liberalization. However, as reported by many global financial institutions, Greece is considered as being a very uncompetitive country, and its economy characterized as very ineffective in terms of efficacy and competitiveness. According to Lynn (2011), Greek industry remains stuck in the past and largely unable to compete in the modern world. Despite a remarkable progress recorded in the financial sector, this was not initiated by national resources, but from external assistance and incentives, which were not used to autonomously expand further growth, but rather developed a dependence relationship with the external environment, especially the EU. All in all, it was inevitable for the economic crisis to badly affect Greece due to a relatively small manufacturing sector and due to a large share of the "shadow economy" which is estimated to be $25 \%-30 \%$ of GDP (Kouretas \& Vlamis, 2010). Conditions began to deteriorate after the collapse of Lehman Brothers and by the time the significant pressure on valuations of Greek government bonds has started, both typified as the warnings of the approaching "storm" (Mylonas, 2013).

The crisis in the Greek economy first started as a crisis of the European financial system and as a result of the recession due to GEC, and subsequently resulted to a general social and political crisis (Kotios et al., 2011). The crisis has further evolved into a liquidity crisis in the regional countries, and then became a debt and solvency crisis, while these days, it is expressed as a continuous crisis of the existence and cohesion of the Eurozone within international dimensions (Shambaugh, 2012). In Eurozone, by the end of 2009, financial markets discovered that the monetary union lacked of fiscal coordination and knowledge of the appropriate procedures so being able to correct problems resulting from competitiveness' differences among the member states. Eurozone's structure weaknesses have even questioned the existence of a common European currency (HBA, 2013). To that end, many analysts predict that the economic crisis in Greece could become the worst recession in modern world history as the majority of the organizations have been negatively affected (Epitropaki, 2012; Thompson, 2012); nonetheless to highlight a decline of over $7.1 \%$ in GDP.

In terms of their HR practices, native organizations failed to equilibrate the negative effects of the recession, as dominated by short-term oriented planning, rather than seeing crisis as an opportunity to push forward their strategic dynamic (Bouas \& Katsimardos, 2012). A study conducted by Glover and Tomek (2012) outlined that Greece is spiraling into this kind of decline in which both US and Germany endured during the Great Depression, showing the scale of the challenge involved in attempting to regain competitiveness through austerity, as the economy shrank $18.4 \%$ in the past four years, while there is a forecast of another $4.6 \%$ in 2013 as Greece struggles to reduce its debt (27\% decline US Economy during 1929-1933, 34\% decline German economy during 1929-1933). Another study, undertaken by Epitropaki (2012) clearly illustrated the severe impact of EC within the Greek economy and its industries by highlighting a considerably (44.9\%) and dramatic (7.5\%) impact of crisis among the investigated industries.

This catastrophe also presents a social and political impact throughout Europe and the rest of the world. However, it has a great impact on the people and companies within Greece itself. 
More precisely, the social impact of the crisis is seen through a record unemployment rate, decreased wage levels, the closure of businesses and an increasing number of people facing social exclusion through wages inequalities among the citizens. Especially, in terms of income inequality, Berg and Ostry (2011) and Berg and Sachs (1998) identified that such disparity can be a significantly hazardous factor to sustained economic growth, as unequal societies are more likely to face serious debt crises. Work in Greece became less secure as, nowadays, more and more employees developed flexible status, like part-time, temporary and fixed-contract work. To that end, employers argue that the benefits of using temporary workforce considered as of great value in terms of "try before you buy", not only at a micro level, but also as means of the organizational efforts for post-recession competitiveness through enhanced flexibility when it comes to staff redundancies along with lower costs and more transparency on their administration (Sarathy, 2010).

Quite similarly to Ireland's case, Greek labor market's increase (especially construction) was higher not only among other sectors at a national level, but also higher than those of other EU member states. Greece and Ireland were in the eye of this financial storm as their banks had become over-exposed to bad debt due to lecherous lending to property developers, and eventually this financial turbulence affected the national economy as a whole (Whelan, 2010; Roche et al., 2011). Honohan (2006) argued that the availability of easy money encouraged the construction industry to expand, property prices to rise, and eventually the domestic spending to catapult. As in Irish recession, the current recession in Greece, is very astute and extended due to a large fall in Gross National Product (GNP), and the rise in closures, layoffs and unemployment (Roche et al., 2011). Greece has experienced a sharper fall in output, and as a result unemployment has wafted. The banking system almost collapsed, while the austerity measures further diminished government finances.

Greek crisis' management, both on the part of the Greek government and the European side, is an example to be avoided (Featherstone, 2011; Kotios et al., 2011). There is no doubt that Greek crisis' management highlighted by a universal failure. The total public debt increased in absolute numbers and as a percentage of GDP compared with that of 2009 (from 129.4\% of GDP in 2009 to $160.2 \%$ in 2012). Despite the unusual "haircut" of the private debt, the repayment extensions and interest rates' cuts, the national debt cannot be regarded as sustainable (Kotios \& Roukanas, 2013). Suffice it to say that the major responsibility rests with the Greek authorities who state control of the economy, mismanaged it and deceived their citizens about the true nature of its budgetary problems. Moreover, Greece has to confront a large and very inefficient public administration, widespread tax evasion, and its political "clientelism" (Nelson et al., 2011: 4-5). In addition, the inability of the credit rating agencies to predict the 2007 US mortgage loan crisis, led them targeting Greece and other European countries since they all had very large budget deficits, and eventually downgraded and led them to withdraw from the international markets (Kouretas \& Vlamis, 2010). Finally, the delayed reaction of the European Central Bank and Eurozone governments to signal their intention to provide help to those countries facing financial problems, illustrated the lack of political union in Europe (Kouretas \& Vlamis, 2010). Furthermore, the continuous pressing social problems and the austerity measures implemented by the Greek government further impacted on Greek 
society. The clearest evidence of this is that over 1 million people lost their jobs since the beginning of the economic recession. In April 2013, the unemployment rate reached 26.4 per cent (EL column) - the highest since Greece joined the Euro zone and the highest within the borders of EU (Eurostat, 2013).

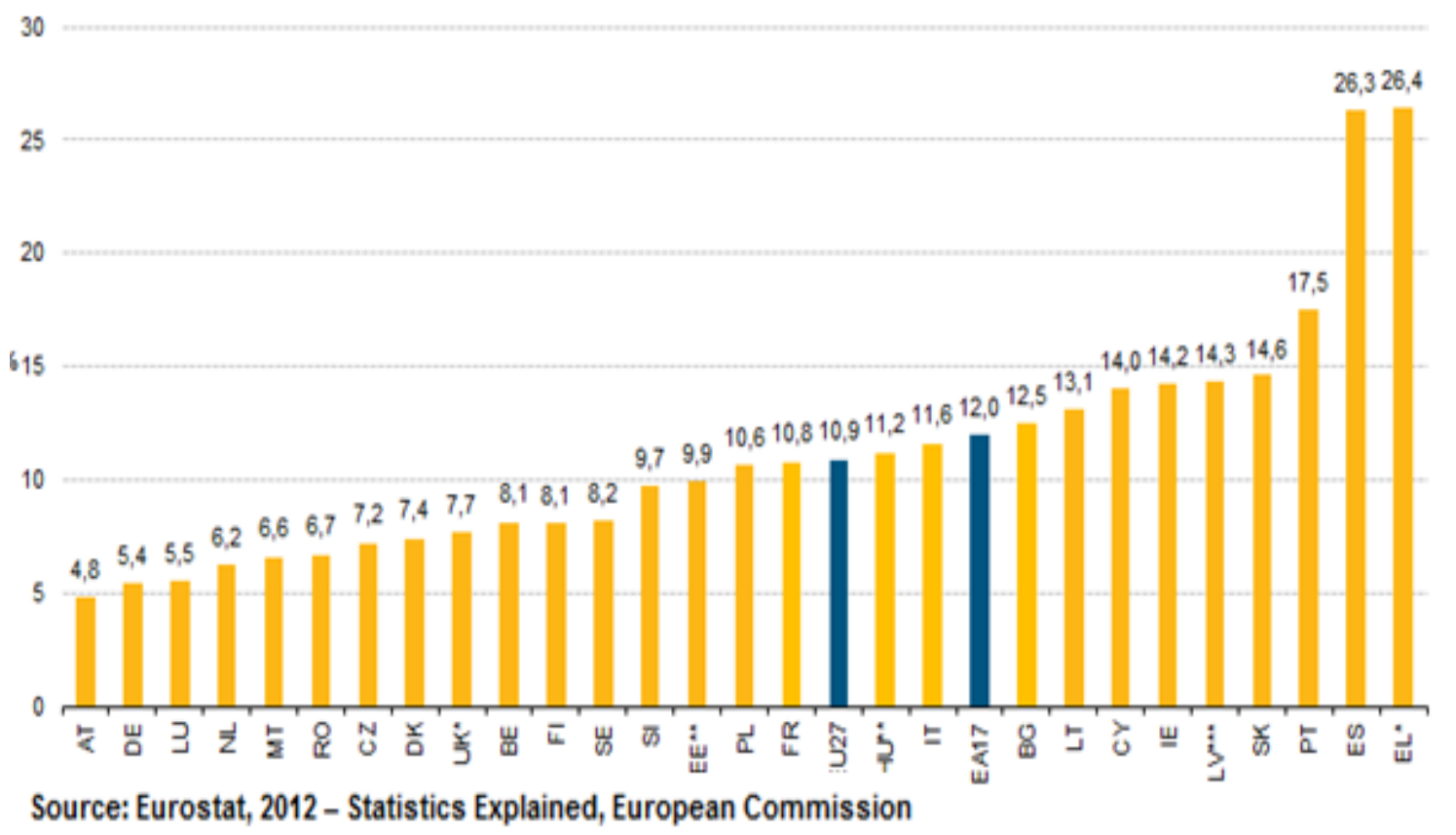

Such high levels of unemployment present two distinct problems for Greece. First, it means that an increasing number of people are being driven to financial ruin because the Greek social security system pays unemployment benefit only for the first 12 months. Of the 1.147 million people that are unemployed at the moment, only, approximately, 480.000 receive state benefits, which are less than 400 Euros per month (Malkoutzis, 2011). A second issue is that Greece has no formal system for helping either young people to enter the job market or middle-aged people who have lost their jobs to retrain for other positions. Therefore, Greece faces the real possibility that some people will join the ranks of the long-term unemployed while others will choose to leave the country. The economic crisis and the on-going depression further resulted in an exodus of talented, ambitious and well educated young Greeks (49.3\%) to other European growing economies, as part of their efforts to find a job (Natsios, 2012; Eurostat, 2013).

Another survey highlighting this workforce mobility, conducted among high school graduates, indicated that seven out of ten graduates are considering working abroad (Malkoutzis, 2011). Furthermore, according to the Recruitment Confidence Index (RCI) which is conducted every 6 months by the Applied Research \& Innovation Department of ALBA Graduate Business School at American College of Greece, there will be a decrease and stagnancy in the recruiting processes in the Greek labor market for the next 6 months. The survey showed that $52.4 \%$ of the companies have been affected either a lot or dramatically by the current financial crisis, while only $1.8 \%$ state that they have not been affected at all. To greatest concern is the fact that $49.7 \%$ of the companies will reduce their employees' executive training (ALBA, 2012). Similar implications of the economic crisis can be viewed in Spain, where the unemployment rate is the 


\section{Macrothink}

Business and Economic Research

ISSN 2162-4860

2014, Vol. 4, No. 1

highest of EU zone, and to Italy, Portugal etc. Companies that survived from the economic crisis, forced to reduce cost by lying off employees and reducing spending. This perpetuates the vicious cycle, increasing unemployment further. Austerity measures place additional pressure on individuals and companies, as the government decrease spending and raise fees. Unlike the Irish government which implemented a program of incentives to encourage employment retention in firms, especially in the export sector, and job placements schemes as a series of labor activation measures to counter the rise of long-term unemployment (Roche \& Teague, 2012: 6), Greek government's measures still remain sluggish or in the wrong way.

All that can be clearly explained through the suggested types of capitalism from Hall and Soskice (2001). According to the authors, there are three varieties of capitalism that demonstrate the ways in which countries react in response to an economic crisis. Therefore, there are "liberal market" economies (LME), "coordinated market" economies (CME), and the called "Mediterranean Model of Economy" (MME), as illustrated below (Hall \& Soskice, 2001; Lallement, 2011: 636-637).

Labour market regulations and varieties of capitalism

\begin{tabular}{llll}
\hline & LMEs & CMEs & MEs \\
\hline $\begin{array}{l}\text { Labour market } \\
\text { characteristics }\end{array}$ & $\begin{array}{l}\text { Weak employment } \\
\text { protection } \\
\text { Secondary and } \\
\text { external markets }\end{array}$ & $\begin{array}{l}\text { Intermediate level } \\
\text { of employment } \\
\text { protection, mobility } \\
\text { facilitated by high } \\
\text { levels of generic } \\
\text { qualifications/skills }\end{array}$ & $\begin{array}{l}\text { Strong employment } \\
\text { protection } \\
\text { Internal markets, } \\
\text { labour market } \\
\text { segmentation }\end{array}$ \\
$\begin{array}{l}\text { Preferred instruments } \\
\text { of employment } \\
\text { adjustment }\end{array}$ & $\begin{array}{l}\text { External flexibility: } \\
\text { redundancies, wage } \\
\text { flexibility }\end{array}$ & $\begin{array}{l}\text { Internal flexibility: } \\
\text { working time, functional } \\
\text { flexibility }\end{array}$ & $\begin{array}{l}\text { Dual flexibility: } \\
\text { protection for the } \\
\text { core labour force and } \\
\text { precarity }\end{array}$ \\
$\begin{array}{l}\text { Main response to } \\
\text { employment crisis }\end{array}$ & $\begin{array}{l}\text { Accentuation of } \\
\text { misadjustments }\end{array}$ & Adaptation to the crisis & $\begin{array}{l}\text { Reinforcement of } \\
\text { inequalities }\end{array}$ \\
\hline
\end{tabular}

Source: Lallement, 2011, p.638 


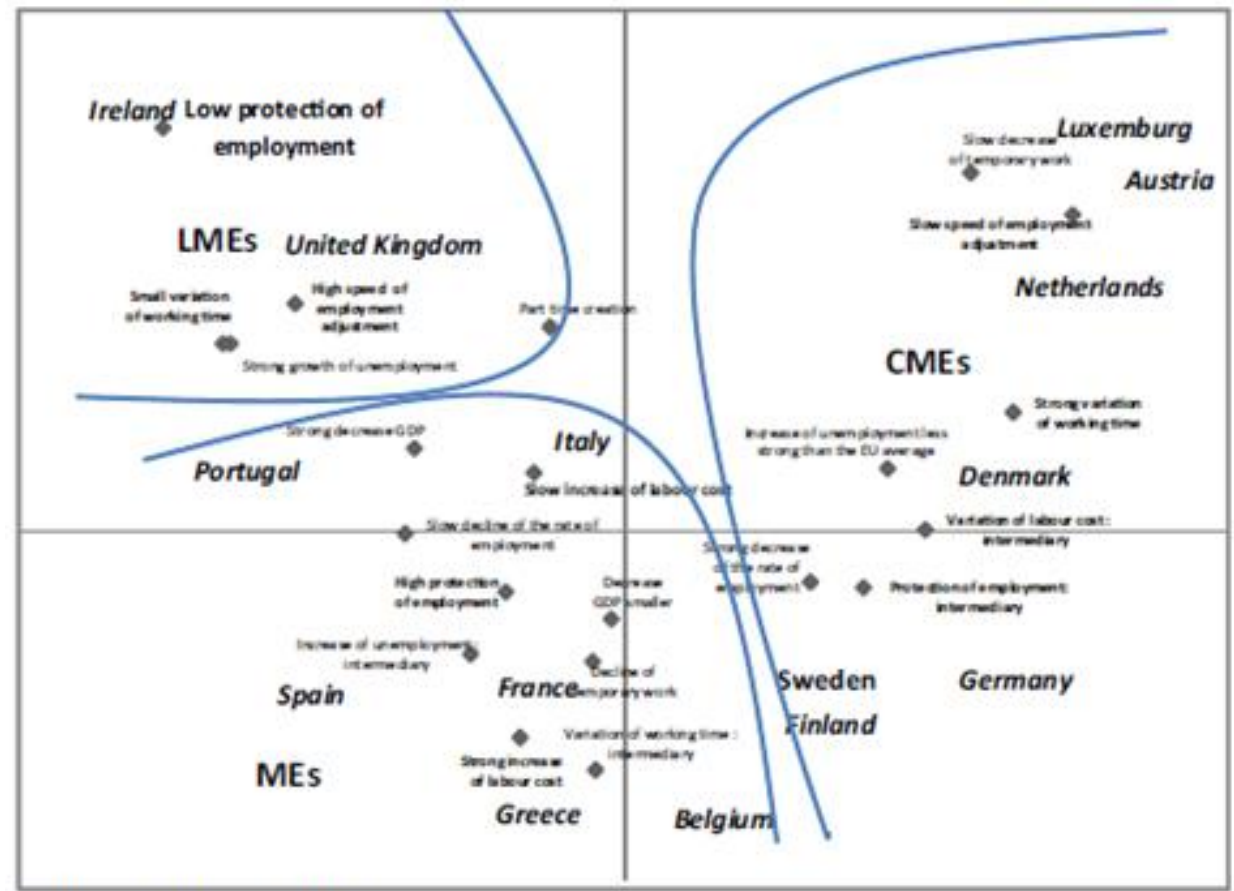

Source: Lallement, 2011, p.638

"Liberal market" economies tend to have controlled public expenditures and limited redistribution of wealth, ungenerous welfare benefits (especially for the poorest society members), high wage flexibility, and their primary source of corporate funding comes from the financial market (Lallement, 2011: 636; Hall \& Soskice, 2001). In contrary, "coordinated market" economies presuppose a more active role of the state, high levels of compulsory taxes and social security withdrawals, a generous welfare system, and a main focus on their banking system as the primal source of funding for their economic activities (Lallement, 2011: 637). Finally, the "Mediterranean model of economy", in which within Greece rests, is characterized by government's extensive intervention, relative weakness of its educational and training systems, and difficulties to implement strategic approaches for high valued outcomes. Eventually, its main response to the economic crisis is the reinforcement of inequalities through increased youth unemployment rate $(64.2 \%)$, continuous cost reduction policies from employees etc. (Lallement, 2011: 637). However, in this type of capitalism variety, banks play an important role in corporate financing.

From the beginning of the economic crisis, the International Monetary Fund (IMF) and the European Union helped Greece with money to attenuate the financial and social impact of the crisis. As a condition for such funds, Greece agreed to liberalize its economy, strengthen its banking system, and improve corporate governance; however, due to these international borrowings, the Greek government could not continue to protect domestic companies from international competition; therefore, restructuring was essential. Local firms forced to upgrade their operations or face bankruptcy if they could not compete. Facing competition means upgrading human capital and exploiting technology to restructure business processes. To that end, and due to the turbulent business environment, HR departments had to effectively handle all these changes, while concurrently to increase productivity while reducing costs. Some are 
forced to change structures, cut benefits, impose wage cuts, dismiss employees and change contracts to more flexible employment (full time (FT) to part time (PT), fewer days of work etc.). However, in short term, gains from such adjustments counterweighted by losses in administrative capacity in the long term (Bouas \& Katsimardos, 2012). Kusku's (2000) study on Turkish economic crisis highlighted that short-term crisis policies were not favored against long-term ones within Turkish organizations. The study outlined organizations' failure to reduce the negative effects and deception created among their employees, by implementing HR practices focusing on behavioral change through short-term focused approaches, rather than adopting strategic, proactive and long-term oriented HR interventions. While coping with this intense workload, HR departments need to realize their value-added capacity through increasing the performance and agility of the talent (human capital) and culture of the organization (Freed et al, 2012).

More precisely in Greece, HR has a rather short history; hence, there is still much room for growth for strategic HR practices within Greek organizations. In past years there has been a trend in countries in south Eastern Europe that shows a decrease in the number of companies where the head of HR was on the board of directors (Apospori et al, 2005). Another study comparing Greek firms with Multinational Companies' (MNC) subsidiaries in Greece reported that "HR planning was found to be less tightly linked with corporate planning in Greek firms than in MNC subsidiaries" (Myloni et al, 2004). Greek companies and their HR departments must strengthen their competency as strategic positioners. As they internalize their understanding of the business context and stakeholder expectations, they will be able to add value by contributing to business strategy that drives critical results. A fine example of proper implementation of its HR practices could be seen in TITAN Group of companies where the HR division plays an active role not only in company's operations but also in its strategy formulation. This is declared in the strategy statement of the group where HR is one of the four pillars of strategy at the same level of importance as the other three business pillars, and every business decision is decided on the basis of these four pillars (Titan Web Site, 2012).

As economic turbulence is directly reflected to society, people who affected by economic changes are likely to stick to traditional beliefs and values. Bourantas and Papadakis (1996) alleged that Greek HR is on the way of overcoming past idiosyncratic flaws. They characterized Greek HR as a western-type management style which has not yet reached the level of modernization, by means of delaying the adoption of scientific and analytic methods and techniques. However, progress in the application of advanced HR techniques in the Greek context is demonstrated by the elevation of the Greek subsidiary of Colgate on the top, as the best European workplace of the year 2006. Colgate Hellas has developed an excellent workplace climate in which about $40 \%$ of the employees have been with the company more than 15 years; voluntary turnover amounts to $3.3 \%$ only; absenteeism also ranges over very low rates $(0.3 \%$ in 2005). The company offers several incentives to its employees such as training days off, numerous sick days, extended annual holiday, early Fridays, and extra parental leave etc. (Myloni, 2002). Even though most of the Greek corporations are HR short-term oriented, in the recent years, there is evidence that, at least the biggest companies seem to embrace a more strategic long-term HR approach (Theriou, 2004). 


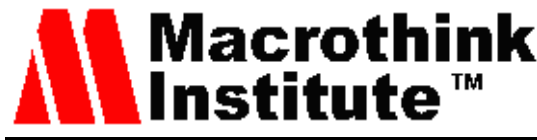

Business and Economic Research

ISSN 2162-4860

2014, Vol. 4, No. 1

From a financial perspective, Greek crisis should be stopped. A crisis in the government bond markets may lead to large losses on the balance sheets of the banks, which this could trigger a new banking crisis in the Eurozone. Furthermore, the crisis will lead to increases in government bond yields in a significant number of Eurozone countries, and may start a domino effect, by setting off a chain of events that would create an economic contagion with severe consequences (Sanati, 2011). This will put pressure on the governments of these countries to sharply contract fiscal policies, leading to deflationary effects and risking pulling down the European economies in a double-dip depression (De Grauwe, 2010). To reach a final resolution of the Greek crisis within the Eurozone that requires coordinated efforts from both sides. On the Greek side, it is required a serious effort to rebuild the country through a broad set of reforms in almost all levels of the economy, politics and the society. The country will never be able to emerge from the crisis if it does not cure the structural causes that led to the collapse. On the other hand, on part of the Eurozone, further acts and less destabilizing and degrading statements are needed. There is a need of elongating fiscal adjustments; a restructuring of the public debt, and a generous liquidity provision and support for the country's development. Problems can be resolved by the time the country will return to high growth rates (Kotios \& Roukanas, 2013). Luckily, recent reports provide evidence that key macroeconomic indicators are now moving in the right direction, and confirm that the adjustment of imbalances in the problem countries is well under way, as competitiveness is on the rise, external imbalances are shrinking, and fiscal rectitude is returning (Heise, 2012). Nonetheless to point out that stimulating economic recovery is important in making labor market adjustments with a view to prevent further social crises (Sarica, 2012). May this crisis be a good lesson for all nations and organizations so to change their business mindset and being more strategic focused and long-term oriented.

\section{Banking Institutions during the Recession}

The financial sector has suffered its worst crisis since the 1929 crash, and although the crisis was heavily concentrated in US and Europe, its effects have spread to financial systems globally and spilled over to the real economies, leading to the deepest world economic downturn since the Second World War (Soriano, 2011). Financial activities are both at the origin of the current GEC and have been strongly affected by the economic instability which impacted organizations' performance and their HR practices respectively (Lahteenmaki et al., 1998). More precisely for Greek banking industry, for many years, banks encouraged their employees to take full advantage of the various Hellenic Banks Association's sponsored education and training opportunities, besides including those offered from within. As a result, the banking sector became widely known as a leader in workforce development. However, with the advent of the GEC, everything changed. The sector has undergone significant change due to fierce competition, merger and acquisition activities, and many other developments occurred by the recession. Inevitably, in times of economic hardship, HR practices are among the first casualties (Felstead et al., 2012a). This assumption is frequently repeated in both general and specialist commentaries on the impact of recession on HR (Kingston, 2009; Charlton, 2008).

The HR function in the banking industry has been transformed in several fundamental ways. First, as HR budgets came under increased scrutiny, much of the responsibility for improving 
job performance and enhancing career potential rests with the employee and not the organization. Bank's previous full responsibility for the long-term development of employees is rapidly disappearing. That trend is expected to continue until employers fully understand the important linkage between HR investments and business performance. Although HR executives indicate that people are their banks' most important asset, relevant expenses are more often considered a cost of doing business rather than an investment, therefore, it can be one of the first areas of any organization which has its budget reduced in times of economic difficulties. Generally, short-term counter-measures, focusing on generating increases in quarterly earnings, take priority over long-term investment strategies, such as people development, which can pay dividends in the future (Felstead et al., 2012b). As a result, in most banks, HR budgets are always at risk. A study by Bassi et al. (2004) indicated that US banks that managed to resist Wall Street's pressure to cut staff costs have outperformed their peers financially and on the stock market, thereby reaping the benefits of fully investing in their people. Similarly, a most recent research report conducted by Miller (2012) reported that organizations' revenues and overall profitability were positively correlated with HR (training) expenditures, regardless of how expenditure was measured, and regardless of whether performance was compared to previous years or to other organizations. A number of other studies pointed to equally impressive conclusions as well. HR investments have been shown to be a key driver of employee retention, which in turn has been linked to improved customer retention, leading to enhanced sales and ultimately overall profitability (IoD, 2009: 11, 22; Bassi et al., 2004). Contrariwise, there are other studies, such a meta-analysis from 67 studies, implemented by Tharenou et al. (2007: 264), which concluded that specific HR practices (e.g. training) do not appear to be related to organizational financial performance. However, according to IoD (2009), organizations that scored highest in innovation tend to spend significantly more on education and workplace learning per employee than do less-innovative firms. In addition, there is ample empirical evidence to show that employee training can reduce attrition, boost staff's morale, and increase recruitment success (p.22).

Accordingly, most of the European banks have been as severely hit by the global financial crisis, with many of them reporting at least three restructurings during the period. Nevertheless to mention that it is not easy to assess the real impact of the global crisis on the banking sector because, before the crisis surfaced, the sector was already experiencing a deep restructuring as a consequence of a strong process of market integration and internationalization during recent decades due to the liberalization in global capital markets, new information technologies and commercial expansion. International markets and analysts realized that GEC is not over yet; therefore, there are several concerns about the banking sector's vulnerability in response to its efforts to alleviate recession's impact (BIS, 2012: 65). Furthermore, the recent GEC is intertwined with an impressive spread of financial innovations and largely attributed to the weaknesses of financial institutions to effectively manage the assessment and evaluation of risks that exist in the modern world of international finance (Moschos \& Chortareas, 2013).

As a response to the crisis, most of the European governments, primary provided financial support to their banking systems, in order to help them facing not only the liquidity but also 
their solvency problems (Lallement, 2011: 629). However, the measures implemented by governments were not sufficient enough to pace with the challenges they have to meet (Watt, 2009). The current European debt crisis and sovereign bond market volatility will pose further challenges to the European banking sector, and will be affected by the general economic situation. Several financial institutions have to be bailed out and public programs of an unprecedented nature should be put in place in order to avoid the collapse of the financial systems. In the EU27 as a whole, 250.000 jobs were lost in the banking sector between 2008 and 2010. This means that employment decreased by $6 \%$, above the average employment reduction in the whole economy $(-2.4 \%)$. In general terms, these decreased employment levels are explained by two opposite trends. On one hand, the privatization and liberalization of the sector resulted in higher profitability, value added and employment, in particular in countries where the sector was less developed. On the other hand, the concentration process of the sector increased the number of redundancies and resulted in job losses even before the crisis, particularly in countries where the sector was already mature and well structured. Jobs in the banking sector have traditionally been considered well protected, with a low incidence of temporary contracts and with higher than average levels of remuneration. However, this favorable outlook for working conditions has been challenged by company strategies to tackle the effects of the crisis. Taking into account Spain's case, the European Commission has recently established a relentless crackdown in exchange for bailout money to banks. It is estimated that there will be a cut of approximately 8,000 jobs in nationalized banks, between direct lay-offs and downsizing, rigged to the sale of close of subsidiaries and the elimination of nearly 1,000 offices (Barron \& Perez, 2012). In nearly all countries (including Greece), banks have implemented cost-saving programs (e.g. wage reductions and moderations) in order to reduce labor costs, while aiming at creating a more flexible workforce with higher productivity (Soriano, 2011).

As Greece is amid the economic crisis, and more or less is mired in the recession, according to Dimitropoulos (2012), the current issues Greek banks facing today are the following:

- Withdrawal of a large amount of deposits (approximately 80 billion 2009-2011) due to the crisis, and the uncertainty about future developments at a European and global level,

- The large share (about 60 billion) of obsolete Greek government bonds in bank portfolios; therefore, a possible default of Greece's debt will lead to a collapse and freeze of the Greek banking system (Sanati, 2011).

- $\quad$ Liquidity problem and high degree of dependence from the European Central Bank and it is currently the main lender of banks, opposed to the old borrowing way (through the interbank market),

- The significant increase in non-performing loans and a concomitant increase in bad debts in 2012,

- Major pressures from the bond swap program (PSI) and greater likelihood of cutting public debt,

- Serious recapitalization needs despite aid packages that have already been provided,

- The decline in equity values and stock capitalization which consistently creates difficulty of implementing future capital increases, 
- Finally, the total assets among the Greek banking sector burdened with a tenfold rise between 2005 and 2011, leading to the system's further containment to absorb the shock of the crisis, as the higher the proportion of its pledged assets, the more vulnerable a bank institution becomes (Dimitropoulos, 2012; BIS, 2012: 72).

Obviously, the Greek banking sector is experiencing unprecedented challenges from the escalating economic crisis which tests system's resilience under the profound recession, Greek debt's restructuring and the overall reduction of the traditional liquidity sources coming from the international markets due to the deterioration of the creditworthiness of the Greek government (Mylonas, 2013). Even worse for banks, Greek economy's outlook still remains gloomy with most analysts foreseeing the economy contracting by 2.5 to 3.5 per cent as fiscal consolidation, private sector wage cuts and high unemployment bite. Consequently, Greek financial crisis' escalation led to a rapid deterioration in the banking system. This gradation centered in Greece in the second half of 2009 and early 2010, created an extremely challenging economic and financial environment. However, Rapanos (2012), president of the Hellenic Bank Association, emphasized the key role of banks in the current period of the economic crisis being experienced by Greece by pointing out that "the banking sector is currently in the middle of the storm, a storm that it is dealing with, with sobriety and without complaint, in order to help the suffering economy and to support the national effort for the tackling of the economic crisis. We deeply believe that Greece has the possibilities to exit from the crisis the country has been experiencing over the past five years, and in this effort the banking system can play a catalytical role". Cihak et al. (2012) also highlighted the paramount importance of financial sector's influence on overall productivity. Moreover, according to Rioja and Valev's (2004) study of 74 countries, the role of the financial sector can be presented as a key driver for national growth. Nevertheless to point out that economic crisis' effect on the banking sector affected other companies as well by limiting their access to credit.

\section{Conclusion}

Apparently, crisis, and the prolonged Greek recession, both resulted in changes within the labor relations and organizations' structures and other operational practices. More precisely, the banking sector is bound to go through the biggest overhaul in decades as local credit institutions take corporate actions and proceed with plans to fill their capital shortfalls on losses incurred by the recession and by their prospective private sector involvement (PSI) participation and future loan diagnostic tests. Additionally, the literature clearly outlines the immediate profound impact of the economic crisis on the way in which organizations have managed their human resources, by indicating more market-oriented and short-term moves instead of proactive, long-term interventions. However, this immediate impact does not necessarily constitute a strong indicator of any other continuing effects which may present. To this extent, banks need to pay greater attention to a more strategic HR approach if they want to achieve organizational growth, maturity and resilience.

\section{References}

ALBA Graduate Business School. (2012). Recruitment Confidence Index for the Greek Labor Market. Research Report (No. September 2012B), Retrieved from ALBA Graduate Business 
School website: http://www.alba.edu.gr/RCI/Documents/RCI\%202012\%20B.pdf [assessed on $10^{\text {th }}$ February 2014].

Apospori, E., Nikandrou, I., \& Papalexandris, N. (2005). Changes in HRM in Europe: A Longitudinal Comparative Study among 18 European Countries. Journal of European Industrial Training, 29(7), 541-560. http://dx.doi.org/10.1108/03090590510621045

Appelbaum, E. (2011). Macroeconomic Policy, labor market institutions and employment outcomes. Work, Employment and Society, 25(4), 596-610. http://dx.doi.org/10.1177/0950017011419711

Bank of International Settlements (BIS). (2012). Post-crisis evolution of the banking sector. BIS 82 ${ }^{\text {nd }}$ Annual Report, Research Paper, pp.64-83, Retrieved from BIS website: http://www.bis.org/publ/arpdf/ar2012e6.pdf [assessed on 10 ${ }^{\text {th }}$ March 2014].

Barron I. and Perez C. (2012). Despidos masivos en las cajas nacionalizadas (Lay-offs in nationalized banks). Retrieved February 10, 2014, from Elpais.com: http://economia.elpais.com/economia/2012/11/24/actualidad/1353789346_922547.html, Translated by Bing - Microsoft Internet Explorer Translator.

Bassi, L., McGraw, K., \& McMurrer, D. (2003). Beyond Quarterly Earnings: Using Measurement to Create Sustainable Growth. Atlanta, GA: McBassi \& Company.

Berg, A.G. and Ostry, J.D. (2011). Inequality and Unsustainable Growth: Two Sides of the Same Coin?, International Monetary Fund (IMF) Discussion Note SDN/11/08. Retrieved from IMF website: https://www.imf.org/external/pubs/cat/longres.aspx?sk=24686.0 [assessed on $2^{\text {nd }}$ March 2014].

Berg, A. G., \& Sachs, J. (1988). The debt crisis: structural explanations of country performance. Journal of Development Economics, $29 \quad$ (3), 271-306. http://dx.doi.org/10.1016/0304-3878(88)90046-6

Boland, R.J. and Tenkasi, R.V. (1995). Perspective making and perspective taking in communities of knowing. Organization Science, 6(4), 350-372. http://dx.doi.org/10.1287/orsc.6.4.350

Bouas, K. and Katsimardos, P. (2012). Strategic Agility in Greek Human Resource Management. Retrieved from Institute for Regulatory Policy Research website: http://www.inerp.gr/en/blog/60-nea-stratigiki-anthropinon-poron-dimosias-dioikisis.html

Bourantas, D., \& Papadakis, V. (1996). Greek Management: Diagnosis and Prognosis. International Studies of Management and Organization, 26(3), 13-22.

Charlton, J. (2008). Training budget cuts predicted by learning and development managers. Retrieved April 2, 2014, from Personnel Today website: http://www.personneltoday.com/hr/training-budget-cuts-predicted-by-learning-and-developm ent-managers/

Cihak, M., Demirguc-Kunt, A., Feyen, H. B. E., \& Levine, R. E. (2012). Benchmarking 
Financial Systems around the World. Policy Research Working Paper (No.WPS6175), 1-58. http://dx.doi.org/10.1596/1813-9450-6175

De Grauwe, P. (2010). The Greek crisis and the future of Eurozone. Retrieved from: http://www.econ.kuleuven.be/ew/academic/intecon/degrauwe/pdg-papers/discussion_papers/ eurointelligence-march-2010.pdf, (pp.1-5) [assessed on $1^{\text {st }}$ February 2014].

Dimitropoulos, N. (2012). Greek Banks'Reaction and the 2012 Blackrock Report. Retrieved from Capitalinvest.gr website: http://www.capitalinvest.gr/info.php?product_id=335 [assessed on $1^{\text {st }}$ march 2014].

Epitropaki, O. (2012). Human Resource Management Strategies during the Economic Crisis. Retrieved from ALBA Graduate Business School website, http://www.alba.edu.gr/RCI/Documents/rci_2011\%20olga\%20final.pdf [assessed on $12^{\text {th }}$ March 2014].

European Commission. (2010). Employment in Europe. (European Commission Report: Catalogue No. KE-AH-10-001-EN-C), Brussels, Retrieved from European Commission website: http://ec.europa.eu/social/main.jsp?catId=738\&langId=en\&pubId=593 [assessed on $20^{\text {th }}$ February 2014].

Eurostat. (2013). Unemployment Statistics. Retrieved from Eurostat website: http://epp.eurostat.ec.europa.eu/statistics_explained/index.php/Unemployment_statistics\#Mai n_statistical_findings [assessed on $5^{\text {th }}$ March 2014].

Featherstone, K. (2011). The Greek Sovereign Debt Crisis and EMU: A Failing State in a Skewed Regime. Journal of Common Market Studies, 49(2), 193-217. http://dx.doi.org/10.1111/j.1468-5965.2010.02139.x

Felstead, A., Green, F. and Jewson, N. (2012a). The Impact of the 2008-2009 Recession on Training at Work: (First Interim Report from February 2010 to September 2010). Briefing Paper, May 2012. Retrieved from UK Commission for Employment \& Skills website: http://www.ukces.org.uk/assets/ukces/docs/publications/training-in-the-recession-first-interim .pdf [assessed on $9^{\text {th }}$ February 2014].

Felstead, A., Green, F., \& Jewson, N. (2012b). An analysis of the impact of the 2008-2009 recession on the provision of training in the UK. Work Employment and Society, 26(6), 968-986. http://dx.doi.org/10.1177/0950017012458016

Freed, A., Hyatt, J., Papachristou, A. and Papalexandris, N. (2012). Greek HRM: Building the Critical Competencies. Retrieved from The RBL Group website: http://rbl.net/index.php/library/display-content-page/greek-hrm-building-the-critical-compete ncies [assesed on $29^{\text {th }}$ March 2014].

Glover, J., \& Tomek, R. (2012). Greece Austerity Diet Risks 1930s-Style Depression: Euro Credit. Retrieved February 8, 2014, from Bloomberg website: http://www.bloomberg.com/news/2012-10-22/greece-austerity-diet-risks-1930s-style-depressi on-euro-credit.html 
Hall, P., \& Soskice, D. (2001). Varieties of Capitalism: The Institutional Foundation of Comparative Advantages. Oxford: Oxford University Press. http://dx.doi.org/10.1093/0199247757.001.0001

Heise, M. (2012). Grexit'fears give way to 'Crexit'optimism - Investors are looking towards an exit from crisis. Financial Times, Retrieved from Bullfax.com website: http://www.bullfax.com/?q=node-\%E2\%80\%98grexit\%E2\%80\%99-fears-give-way-\%E2\%80 $\% 98$ crexit\%E2\%80\%99-optimism [assessed on $10^{\text {th }}$ January 2014].

Hellenic Bank Association (HBA). (2013). The Greek Banking System in 2011 and 2012. Hellenic Bank Association Research Report 2013. (pp.31-77), Retrieved from HBA website: http://62.1.43.74//Main/Ereunes-meletes/EllinikoTrapezikoSystima2011-12web.pdf [assessed on $5^{\text {th }}$ March 2014].

Honohan, P. (2006). To What Extent Has Finance Been a Driver of Ireland's Economic Success?, Quarterly Economic Commentary, Special Articles, Economic and Social Research Institute (ESRI), 2006.2006 (4) 59-72.

Institute of Directors (IoD). (2009). Training in the Recession: Winner or Loser?, IoD Survey Report, June 2009, (pp.1-40). Retrieved from Institute of Directors (IoD) website: http://www.iod.com/influencing/policy-papers/education-and-skills/training-in-the-recessionwinner-or-loser [assessed on $5^{\text {th }}$ January 2014].

Kingston, P. (2009). Beware false economies. Retrieved February 12, 2014, from "The Guardian" website: http://www.guardian.co.uk/thetraininggame/beware-false-economies

Kotios, A., Galanos, G., \& Pavlidis, G. (2011). Greece and the Euro: The Chronicle of an $\begin{array}{llll}\text { Expected } \quad \text { Collapse. } & \text { 263-269. }\end{array}$ http://dx.doi.org/10.1007/s10272-011-0390-7

Kotios, A., \& Roukanas, S. (2013). The Greek Crisis and Eurozone's Governance. In Sklias, P. and Tzifakis, N. (2013). Greece's Horizons: Reflecting on the Country's Assets and Capabilities. The Konstantinos Karamanlis Institute for Democracy series on European and International Affairs, Centre for European Studies Publications, (pp.91-105). Retrieved from: http://link.springer.com/chapter/10.1007\%2F978-3-642-34534-0_8

Kouretas, P.G. and Vlamis, P. (2010). The Greek Crisis: Causes and Implications. Panoeconomicus, 57 (4), 391-404. http://dx.doi.org/10.2298/PAN1004391K

Kusku, F. (2000). Do Periods of Crisis Affect Human Resource Management Applications?: The Case of the Turkish Textile Industry. First International Joint Symposium on Business Administration: "Challenges for Business Administrators in the new Millennium", pp.108-114, Retrieved from http://www.opf.slu.cz/vvr/akce/turecko/pdf/Kusku.pdf [assessed on $29^{\text {th }}$ February 2014].

Lahteenmaki, S., Storey, J., \& Vanhala, S. (1998). HRM and Company Performance: The Use of Measurement and the Influence of Economic Cycles. Human Resource Management Journal, 8(2), 51-65. http://dx.doi.org/10.1111/j.1748-8583.1998.tb00166.x 
Lallement, M. (2011). Europe and the Economic Crisis: Forms of Labour Market Adjustment and Varieties of Capitalism. Work, Employment and Society, 25(4), 627-641. http://dx.doi.org/10.1177/0950017011419717

Lynn, M. (2011). Bust: Greece, the Euro, and the Sovereign Debt Crisis. New Jersey: John Wiley \& Sons.

Malkoutzis, N. (2011). Greece - a year in crisis. Retrieved February 10, 2014, from: http://www.opendemocracy.net/nick-malkoutzis/greece-\%E2\%80\%93-year-in-crisis

Miller, L. (2012). ASTD State of the Industry Report: Organizations continue to Invest in Workplace Learning. Research Report (No. 790401E), Retrieved from CPP website: http://people.cpp.com/rs/cpp/images/ASTD-Report.pdf [assessed on $14^{\text {th }}$ April 2014].

Moschos, D., \& Chortareas, G. (2013). Financial systems and economic activity. In HBA Report (2013). The global crisis, the Eurozone crisis and the Greek financial system. Section 1: The role of the financial sector in the course of the economic development. (In Greek, pp.53-67). Retrieved February 12, 2014, from: http://62.1.43.74/5Ekdosis/UplPDFs//syllogikostomos/2-a\%20Moschos-Xortareas53-66.pdf

Mylonas, P. (2013). The Greek banking System in 2011 and 2012. In HBA Report (2013). The Greek Banking System: A Survival strategy in an environment of unprecedented challenges. (pp.51-58). Retrieved February 12, 2014, from HBA website: http://62.1.43.74//Main/Ereunes-meletes/EllinikoTrapezikoSystima2011-12web.pdf

Myloni, B. (2002). The Transfer of Human Resource Management Practices within Multinational Companies in Greece - A Comparative Analysis of Human Resource Management Practices in Subsidiaries of European and US Multinationals and Greek Companies. (Unpublished PhD thesis), School of Management, University of Bradford.

Myloni, B., Harzing, A-W. and Mirza, H. (2004). Human Resource Management in Greece: Have the colors of culture faded away?, International Journal of Cross Cultural Management, 4 (1), 59-76. http://dx.doi.org/10.1177/1470595804041527

Natsios, A. (2013). A Way Out of the Greek Financial Crisis. Retrieved March 5, 2014, from US News website: http://www.usnews.com/opinion/blogs/world-report/2012/12/31/a-way-out-of-the-greek-finan cial-crisis

Nelson, M. R., Belkin, P., \& Mix, E. D. (2011). Greece's Debt Crisis: Overview, Policy Responses, and Implications. Congressional Research Service, CRS Report for Congress (No. R41167), pp.1-24, Retrieved from: http://www.fas.org/sgp/crs/row/R41167.pdf

Rapanos, V. (2012). Banking Sector Key in Greece Exiting Crisis. Retrieved Febrary 10, 2014, from: http://ru.cbonds.info/news/item/575769

Rioja, F., \& Valev, N. (2004). Finance and the Sources of Growth at Various Stages of Economic Development. Economic Inquiry, 42(1), 127-140. http://dx.doi.org/10.1093/ei/cbh049 
Roche, K. W., \& Teague, P. (2012). Do Recessions Transform Work and Employment? Evidence from Ireland. British Journal of Industrial Relations, Early View (Online Version of Record published before inclusion in an issue), Blackwell Publishing Ltd/London School of Economics 2012, November 2012, 1-25.

Roche, K.W., Teague, P., Coughlan A. and Fahy, M. (2011). Human Resources in the Recession: Managing and Representing People at Work in Ireland. Final Report Presented to the Labor Relations Commission January 2011, pp.1-48, Retrieved from: http://www.lrc.ie/documents/symposium11/Exec-Summary-Human-Resources-in-the-Recessi on.pdf

Sanati, C. (2011). End of the line: What a Greek default means. Retrieved from: http://finance.fortune.cnn.com/2011/06/17/end-of-the-line-what-a-greek-default-means/ [assessed on $10^{\text {th }}$ January 2014].

Sarathy, P. (2010). HR Practices during Recession and Post Recession Planning. Mumbai Business School (Dr. Sunil Rai), August 2010, Retrieved upon request to the author through LinkedIn Professional Network, pp.1-15.

Shambaugh, J.C. (2012). The Euro's Three Crises. Brussels. Brookings Papers on Economic Activity, pp.157-231, Retrieved January 15, 2014 from Brookings.edu website: http://www.brookings.edu/ /media/Projects/BPEA/Spring\%202012/2012a_Shambaugh.pdf

Soriano, V.C. (2011). Recession and social dialogue in the banking sector: a global perspective. (European Foundation for the Improvement of Living and Working Conditions Report, ef1115), Retrieved from Eurofound website: http://www.eurofound.europa.eu/publications/htmlfiles/ef1115.htm [assessed on $15^{\text {th }}$ March 2014].

Soykut Sarica Y. P. (2012). Social Responses to Turkey's Recent Economic Crises of 2008-2009. Journal of Social Policy Conferences, 61, 133-151.

Tharenou, P., Saks, A. and Moore, C. (2007). A review and critique of research on training and organizational-level outcomes. Human Resource Management Review, 17(3), 251-273. http://dx.doi.org/10.1016/j.hrmr.2007.07.004

Theriou, N. G. (2004). The Long-Range Objectives and Targets and the Relationship between Them: A Survey of the Top Greek Companies. Review of Economic Sciences, 4(6), 145-160.

Thompson, D. (2012). Greece Is on Pace for the Worst Recession in Modern History. Retrieved February 20, 2014, from The Atlantic website: http://www.theatlantic.com/business/archive/2012/02/greece-is-on-pace-for-the-worst-recessi on-in-modern-history/253128/

Titan Web Site (2012). Titan's Strategic Pillars. Retrieved February 23, 2014, from Titan website: http://www.titan.gr/el/titan-group/governing-objective/_

Watt, A. (2009). A quantum of solace? An assessment of fiscal stimulus packages by EU member states in response to the economic crisis. Working Paper (No.2009.05), European 
Trade Union Institute (ETUI), Brussels, pp.1-42, Retrieved from: http://www.etui.org/Publications2/Working-Papers/A-quantum-of-solace-An-assessment-of-fi scal-stimulus-packages-by-EU-Member-States-in-response-to-the-economic-crisis/

Whelan, K. (2010). Policy Lessons from Ireland's Latest Depression. Economic and Social Review, 41(2), 225-254.

\section{Copyright Disclaimer}

Copyright reserved by the author(s).

This article is an open-access article distributed under the terms and conditions of the Creative Commons Attribution license (http://creativecommons.org/licenses/by/3.0/). 